\title{
weves
}

Journal Of Al Azhar University Engineering Sector

Vol. 12, No. 42, January, 2017, 167-174

\section{COSTING THE HEALTH AND SAFETY IN THE EGYPTIAN BUILDING CONSTRUCTION PROJECTS}

\author{
Mohamed Magdy Giessa ${ }^{1}$, Ibrahim Abdul Rashid ${ }^{2}$, Sameh Abu El-Soud ${ }^{3}$, \\ and Abdel Hamid El-Tahan ${ }^{3}$
}

The Arab Contractors, Osman Ahmed Osman \& Co. ${ }^{1}$

Department of Construction and Building Engineering, Faculty of Engineering, Ain Shams University ${ }^{2}$, and Department of Construction and Building Engineering, College of Engineering and Technology/ Arab Academy for Science and Technology and Maritime Transport, Cairo- Egypt ${ }^{3}$

تعد الحو ادث و الإصـابات في مو اقع الإنشاء من المشكلات الرئيسية على الصعيد المحلى والعالمي، ومن المعروف أن تفاصبل

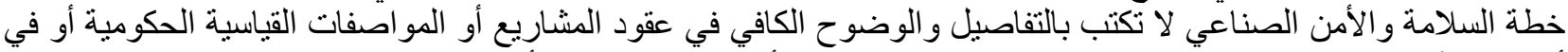

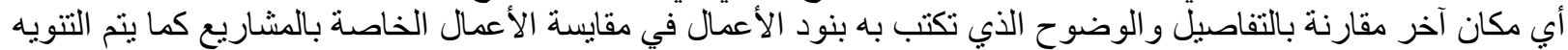

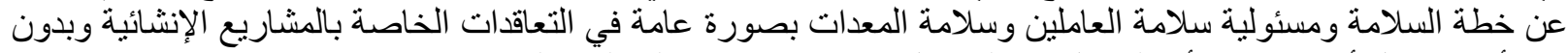
ذكر أية تفاصيل أخرى سوي أن المقاول هو المسئول عن سلامة جميع العاملين بالموقع.

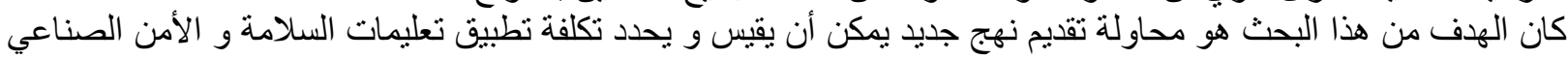

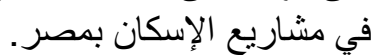

لم تصمم هذه الرسالة لتبتكر خططا استر اتيجية جديدة أو بر امجا تتفيذية جديدة لإجر اءعات التئ السلامة و الأمن الصناعي بالموقع كما

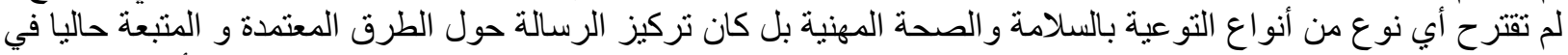

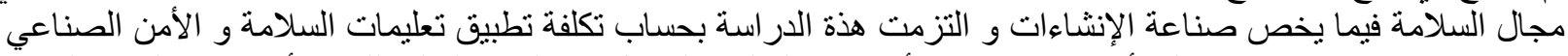

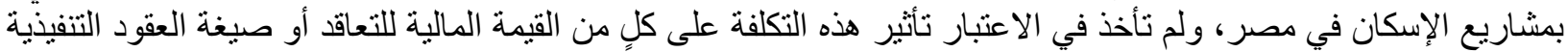

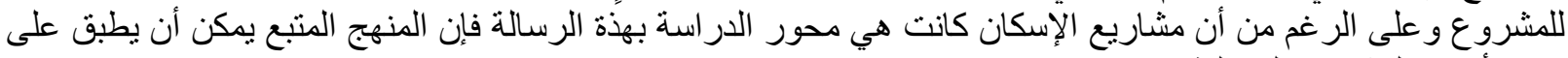
جميع أنواع المشاريع المختلفة.

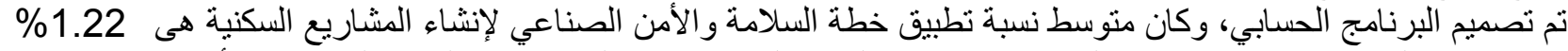

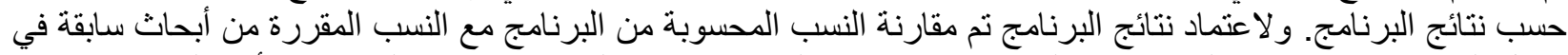
مجال السلامة وكانت نتائج البرنامج مقبولة وبمكن الاعتماد عليها في تقدير تكلفة تطبيق خطة السلامة و الأمن الصنائ الصناعي.

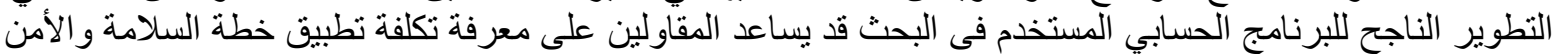

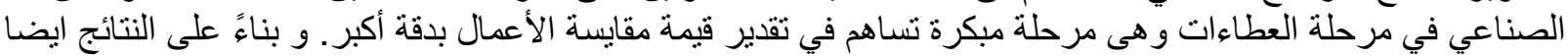

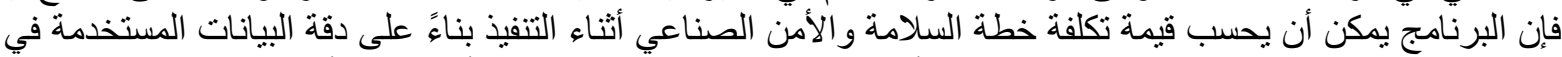

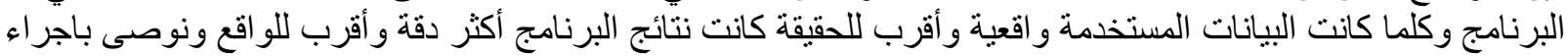
ابحاث اخرى لتطوير البرنامج البر البيان المستخدم.

\begin{abstract}
:
This study described the steps followed in developing an integrated model designed to estimate the cost of health and safety during construction of residential projects in Egypt. The intention of developing this model was to help owners, investors, and engineers to generate an idea about the desired safety budget needed to complete the proposed project before the actual start of the construction and during the bidding stage. This paper represents three case studies in which the health and safety costs for the construction project came to approximately $1.22 \%$ of the total cost of the budget. Although the size of the sample was not large, the results were supportive of the other studies, and indicated that the
\end{abstract}


findings, in general, can be applied to a variety of project settings. The model can provide users with the option to modify the cost of any elements needed in health and safety from the detailed list that was entered in the model; and to implement all necessary adjustments in an easy and efficient way, by changing the elements values associated with the health and safety. On the other hand, this model was designed to be easy to use and flexible and it executes necessary calculations in a quick and accurate way.

\section{Keywords: Health and Safety, Building Project, Model Cost}

\section{INTRODUCTION}

The construction industry is well known for its complexities and inefficiencies in dealing with human safety and construction processes. The industry itself has been notorious for its high casualty records over many years. According to reports published by the Construction Industry Institute (CII), injuries and fatalities occur in the construction industry at a rate more than $50 \%$ higher than all other industries, (Kartam and Bouz 1998).

In Egypt, the concept of improving safety in construction sites has only started to be developed in recent years. Every year, many construction site workers are killed or injured as a result of their work, others suffer ill health. Therefore, the importance of health and safety has come, (Ho, D., Ahmed, S., Kwan, J., and Ming, F. 2000).

The optimum financial resourcing of health and safety is marginalized by competitive tendering, which does not ensure an equitable basis for estimating and bidding because generally, there are no detailed items included for health and safety in contract documents such as Bills of Quantities, (Smallwood, J. and Emuze, F. 2014).

The objective of this study is to introduce a novel approach that clarifies the cost of applying safety regulations in constructing of building projects in Egypt.

The paper will first go through a detailed description of health and safety parameters and safety regulations during construction. Second, a questionnaire was care-fully designed to select the health and safety parameters that relate to constructing residential projects in Egypt. Then, all data were analyzed and built in formula tables, alternatives of the safety plan for the site and labors, component of safety's facilities in the project, techniques of controlling the safety, types of expected hazards and tools needed to apply the safety in the workplace. Next, a simple-to-use spreadsheet model was created to determine the cost of applying the safety plan functioned in factors such as number of labors, area of the project, the volume of work needed and types of equipment used. Finally, the result of applying the created model in three residential projects to calculate the ratio of applying safety plan cost to the tender price.

This study does not try to propose any new safety strategy, program, or awareness system. Rather, it focuses on the current methods used by safety officials in the industry. The scope of this study covers the cost of applying the health and safety regulation in the building projects without taking into account the effect of that cost in the tender price or the contracting formula. Although housing projects are considered in this study, the approach is general and can easily be adapted on other types of project.

\section{Detailed Safety Plan of Construction}

The key to achieving healthy and safe working conditions is to ensure that health and safety issues are planned, organized, controlled, monitored and reviewed.

This part of paper discusses ten sections that may provide the demand for safe, as shown in Table1 , healthy and comfort working environment in constructing building projects by collecting data and information from past researchers, published books, articles and journals that contributed to the construction health and safety design and management. Safety plan regulations are related into building projects referred to Saudi Aramco Construction Safety Manual 1993, and Arab Contractors Safety Manual 2005. 
Table-1 Detailed Safety Plan of Construction

\begin{tabular}{|c|c|}
\hline Section & Sub-Section \\
\hline 1- Setting up the Site & 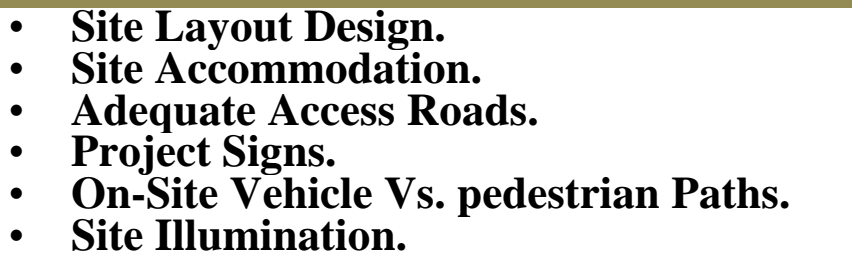 \\
\hline 2- Welfare Facilities & $\begin{array}{ll}\text { - } & \text { Medical Facilities/Suppliers. } \\
\text { - } & \text { Designated Smoking Areas. } \\
\text { - } & \text { Toilet Facilities/Sanitation. } \\
\text { - } & \text { Eating Facilities. }\end{array}$ \\
\hline 3- PPE & $\begin{array}{ll}- & \text { Head Protection. } \\
\text { - } & \text { Eye and Face Protection. } \\
\text { - } & \text { Hand Protection. } \\
\text { - } & \text { Foot Protection. } \\
\text { - } & \text { Hearing Protection. }\end{array}$ \\
\hline 4- Fire Prevention & $\begin{array}{l}\text { - Water-Type Fire Extinguisher. } \\
\text { - } \quad \text { Carbon-Dioxide Type Extinguisher } \\
\text { - Dry-Chemical Type Extinguisher }\end{array}$ \\
\hline 5- Excavation & $\begin{array}{l}\text { - Shoring Protective Systems. } \\
\text { - Inspection. } \\
\text { - Clearance. } \\
\text { - Access and Egress. }\end{array}$ \\
\hline 6- Scaffolding & $\begin{array}{ll}: & \text { Foundations. } \\
\text { - } & \text { Posts. } \\
\text { - } & \text { Runners. } \\
\text { - } & \text { Bearers. } \\
\text { - } & \text { Bracing. } \\
\text { - } & \text { Ties. } \\
\text { - } & \text { Platform Units. } \\
\text { - } & \text { Access. }\end{array}$ \\
\hline 7- Concrete Formwork & $\begin{array}{l}\text { Vertical Slip Forms. } \\
\text { - Tube and Coupler Shoring. }\end{array}$ \\
\hline $\begin{array}{l}\text { 8- Crane and Lifting } \\
\text { Devices }\end{array}$ & $\begin{array}{ll}- & \text { Competent Persons. } \\
\text { - } & \text { Crane Operations } \\
\text { - } & \text { Safe Working Load (SWL). } \\
\text { - } & \text { Wire Rope. } \\
\text { - } & \text { Damaged Slings. } \\
\text { - } & \text { Hooks. } \\
\text { - } & \text { Shackles. } \\
\text { - } & \text { Rigger. } \\
\text { - } & \text { Prerhead Power-Lines. } \\
\end{array}$ \\
\hline 9- Electrical & $\begin{array}{l}\text { - Temporary Installation } \\
\text { - Hand Tools and Lighting }\end{array}$ \\
\hline 10- Heavy Equipment & $\begin{array}{ll}- & \text { General Requirements } \\
\text { - } & \text { Dumpers and Dump Trucks } \\
\text { - } & \text { Graders, Dozers, Scrapers, Loaders and } \\
\text { - } & \text { Fork-Lifi loaders } \\
& \text { Trucks }\end{array}$ \\
\hline
\end{tabular}




\section{Questionnaire Composition}

The questionnaire was used for the purpose of collecting data and information experienced people in the field. Thus, field visits were made to different contractors in Egypt. The discussions were collected and studied carefully in order to develop the questionnaire format. Also, the literature review established the basis of the questionnaire development. Some questionnaire forms which were appropriate to this study from other studies were reviewed. This investigation was necessary to ensure that the structured questionnaire covers the full dimensions of the subject. At the same time, it allowed the researcher to know how to deal with various interviewing situations and to improve the questioning process.

\section{Sampling Approach}

The sample survey was selected from the Egyptian Federation for Construction \& Building Contractors. The first three grades that were qualified and registered in the Egyptian Federation for Construction and Building Contractors in Cairo only, second or third grade was considered as large companies and would have a chance to participate. The method of sampling used was random sampling. Random numbers were used to select the sample contractors from the contractor list prepared by the Egyptian Federation for Construction \& Building Contractors.

\section{Model Description}

The overall model was developed in four stages, as shown in Figure-1, first stage is data input, in this stage user have to enter some required data from his project and these data are given symbols in order to use them in stage three as mathematical equations. Second stage is database of unit price which are tables defining the cost of all materials per unit that will be used in the project. Third stage is analysis, in this stage the model will calculate the cost of health and safety of the project according to the project data given by the user. Forth stage is output \& reports, in this stage the user will find a detailed report that explains the cost of health and safety expected in that project according to the input data and database of unit price which were given before.

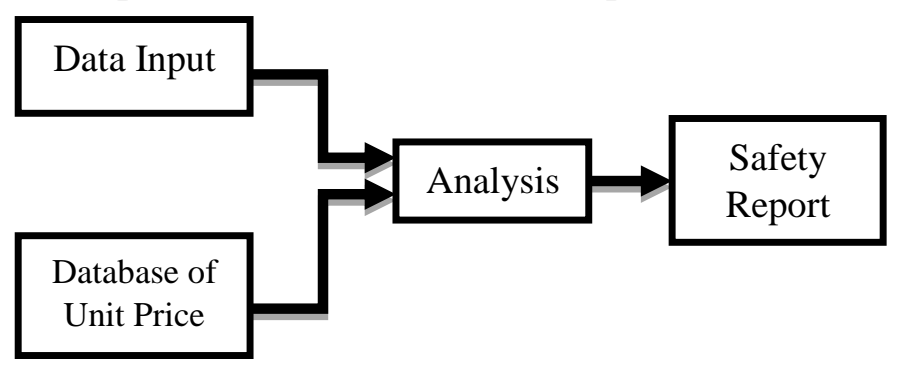

Figure-1: Flow Chart of Model Processes

Data Input: The inputs of the proposed model are considered the main factors that have a high impact on the cost of applying health and safety regulation during the construction project. Unit Price Database: All materials and tools used for safety in the site are dragged in tables. These tables define and describe all units and their prices for every material and tool. These tables used in the model as a temporary database however, the user can modify all prices or keep them in their default values. Analysis: Equations \& relations between data input that mentioned previously and safety regulations during construction.

\section{Projects' Data for Case Study}

The developed model in the previous chapter can be applied to a three residential projects. Project's name, tender price cost and contract duration for each project is shown in Table-2.

Table-2 Projects' Information

\begin{tabular}{|c|l|c|c|c|}
\hline$\#$ & Project Name & Area $\left(\mathrm{m}^{2}\right)$ & Contract Duration (month) & Tender Price (L.E) \\
\hline$\# 1$ & Student Housing & 6415 & 6 & $29,333,291$ \\
\hline$\# 2$ & Al-Fatth Project & 83850 & 36 & $76,144,295$ \\
\hline$\# 3$ & Social Housing & 15300 & 18 & $42,500,000$ \\
\hline
\end{tabular}




\section{Results:}

Using the student housing project data in the developed model to compute the cost of applying health and safety during construction, the expected cost of health and safety during the construction was 310,590 L.E. The model classified the cost into seven sections, personal protective equipment (PPE) had the major cost with $57 \%$ of the safety cost, toilets represented $16 \%$ of the safety cost, while extra safety component in scaffolds represented $11 \%$, medical services are $8 \%$, fire prevention extinguisher cost $4 \%$ and finally both of site illumination and signs are represented $2 \%$ for each. The summary results of safety cost are presented in Table-3 and illustrated in Figure-2 where 100\% of the Total Safety cost was equal to $1.06 \%$ of the project's total tender price.

Table-3 Expected Health and Safety Expenses, Project \#1

\begin{tabular}{|c|c|c|c|}
\hline Safety Items & \multicolumn{2}{|c|}{ Item Cost } & Item Percent \\
\hline PPE & L.E & 175,789 & $57 \%$ \\
\hline Medical Service & L.E & 24,931 & $8 \%$ \\
\hline Toilets & L.E & 50,400 & $16 \%$ \\
\hline Signs & L.E & 5,011 & $2 \%$ \\
\hline Illumination & L.E & 7,920 & $2 \%$ \\
\hline Scaffolds & L.E & 34,609 & $11 \%$ \\
\hline Fire Prevention & L.E & 11,930 & $4 \%$ \\
\hline Total Safety cost & L.E & 310,590 & $100 \%$ \\
\hline
\end{tabular}

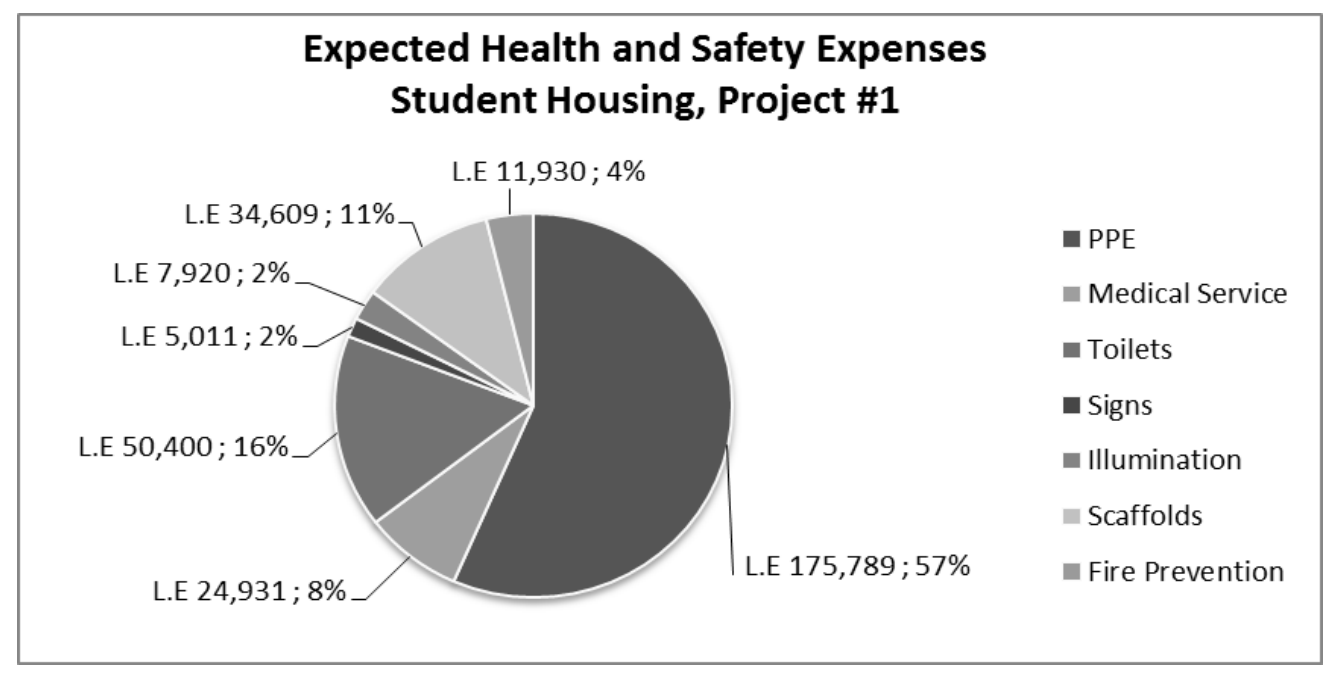

Figure-2 Expected Health and Safety Expenses, Project \#1

According to the results of the developed model in project \#1, the safety cost was 310,590 L.E which was equal to $1.06 \%$ of the project's total tender price. This ratio have suggested to be acceptable and within range according to previous researches conducted in costing of safety, such as Wells and Hawkins, 2009 and Smallwood and Emuze, 2014.

Using Al-Fatth (5) project data in the developed model to compute the cost of applying health and safety during construction, the expected cost of health and safety during the construction was 985,442 L.E. The model classified the cost into seven sections, Toilets had the major cost with $38 \%$ of the safety cost, Personal Protective Equipment (PPE) represented 23\% of the safety cost, while both of medical services and extra safety component in scaffolds represented $14 \%$, fire prevention extinguisher cost $6 \%$ and finally both of site illumination and signs are represented 2\% and 3\% respectively. The summary results of safety cost are presented in Table- 4 and illustrated in Figure- 3 . where $100 \%$ of the Total Safety cost was equal to $1.29 \%$ of the project's total tender price. 
Table-4 Expected Health and Safety Expenses, Project \#2

\begin{tabular}{|l|cc|c|}
\hline Safety Items & \multicolumn{2}{|c|}{ Item Cost } & Item Percent \\
\hline PPE & L.E & 226,270 & $23 \%$ \\
\hline Medical Service & L.E & 139,612 & $14 \%$ \\
\hline Toilets & L.E & 378,000 & $38 \%$ \\
\hline Signs & L.E & 24,909 & $3 \%$ \\
\hline Illumination & L.E & 20,448 & $2 \%$ \\
\hline Scaffolds & L.E & 139,993 & $14 \%$ \\
\hline Fire Prevention & L.E & $\mathbf{5 6 , 2 1 0}$ & $6 \%$ \\
\hline Total Safety Cost & L.E & $\mathbf{9 8 5 , 4 4 2}$ & $\mathbf{1 0 0 \%}$ \\
\hline
\end{tabular}

According to the result of the developed model in project \#2, the safety cost was 985,442 L.E which was equal to $1.29 \%$ of the project's total tender price. This ratio have suggested to be acceptable and within range according to previous researches conducted in costing of safety, such as Wells and Hawkins, 2009 and Smallwood and Emuze, 2014.

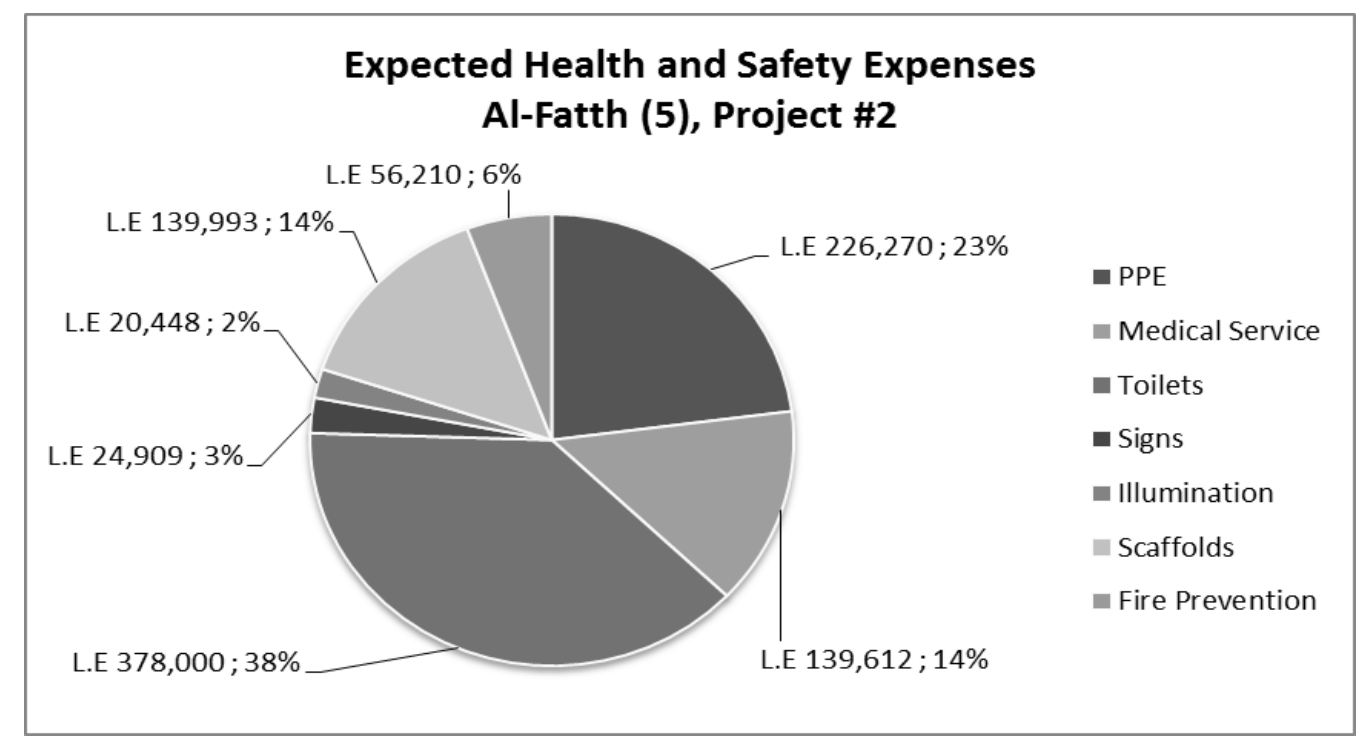

Figure-3 Expected Health and Safety Expenses, Project \#2

Using Social Housing project data in the developed model to compute the cost of applying health and safety during construction, the expected cost of health and safety during the construction was 551,250 L.E. The model has classifies the cost into seven sections, Toilets has the major cost with $27 \%$ of the safety cost, Personal Protective Equipment (PPE) represent $36 \%$ of the safety cost, while extra safety component in scaffolds represent $11 \%$, medical services are $13 \%$, fire prevention extinguisher cost $6 \%$ and finally both of site illumination and signs are represent $4 \%$ and $3 \%$ respectively. The summary results of safety cost are presented in Table-5and illustrated in Figure-4. where $100 \%$ of the Total Safety cost was equal to $1.30 \%$ of the project's total tender price. 
Table-5 Expected Health and Safety Expenses, Project \#3

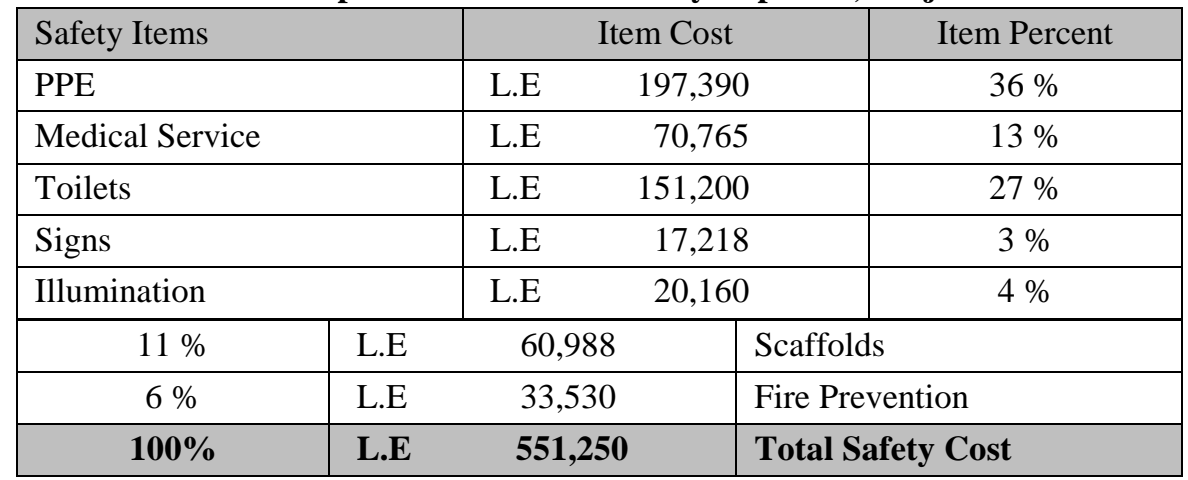

According to the result of the developed model in project \#3, the safety cost was 551,250 L.E which was equal to $1.30 \%$ of the project's total tender price. This ratio have suggested to be acceptable and within range according to previous researches conducted in costing of safety, such as Wells and Hawkins, 2009 and Smallwood and Emuze, 2014.

The developed model has the following advantages:

1. It has the ability to expect the cost of health and safety needed through construction of residential projects at the project's bidding stage.

2. It is easy, user friendly, flexible and executes quick calculations.

3. It generates professional output reports in a quick and efficient way.

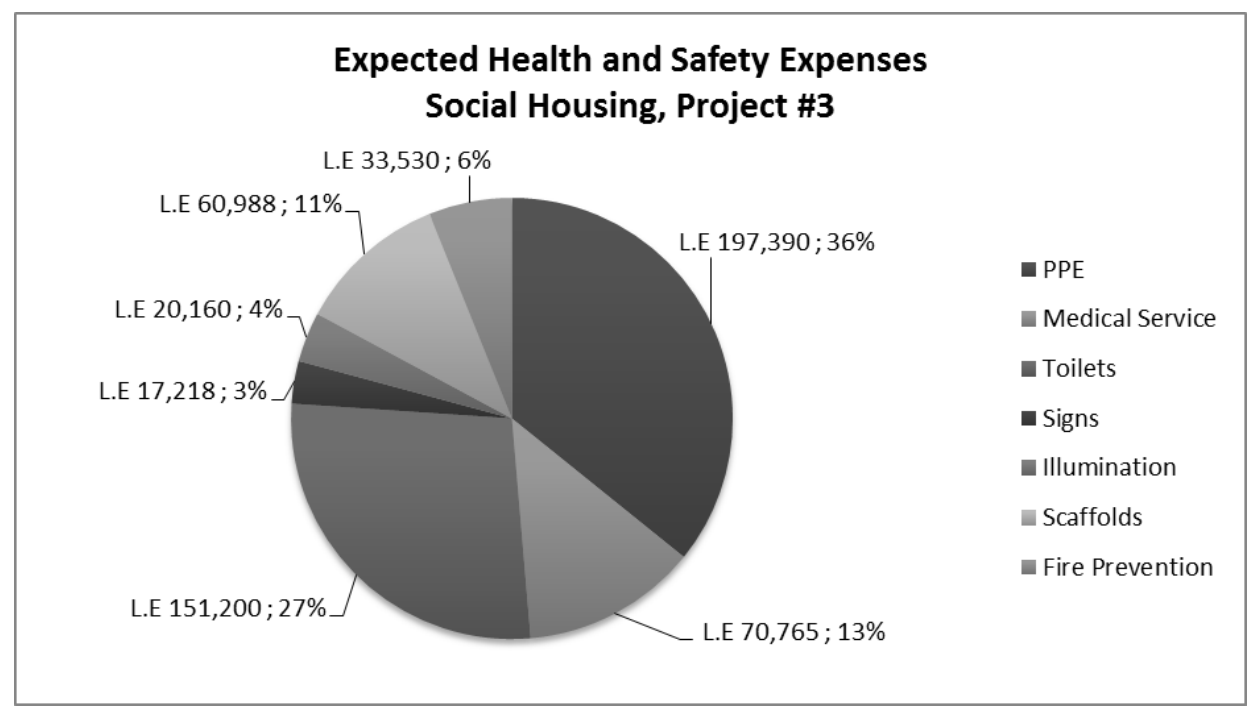

Figure-4 Expected Health and Safety Expenses, Project \#3

\section{Limitation of the Developed Model}

The model can be used for estimating the direct cost needed during the construction of residential building projects in Egypt. General contractors cannot use this model to prepare safety cost estimate of any other type of projects.

Moreover, the model does not execute any adjustment for the daily number of labors (man-power) which is considered as constant number during the construction.

\section{Recommendations for Future Expansion}

Despite the ability of the developed model to generate conceptual estimates for the cost of health and safety for building projects, the model can be enhanced by adding the following features:

1. Include more equations to adjust the duration of each activity entered in the model to generate the optimum number of labors during the construction of the project.

2. Incorporate the effect of health and safety cost in the total cost of the project.

3. Generate a written form in project contracts for detailed health and safety roles involved in constructing residential projects.

4. Integrate the model with 3D modeling by using the Building Information Modeling concepts. 


\section{REFERENCES}

[01] Wilson, Joe. M. Jr., and Koehn Enno (2000):"Safety Management: Problems Encountered and Recommended Solutions", Journal of Construction Engineering and Management, pp. 77-79.

[02] Ho, D., Ahmed, S., Kwan, J., and Ming, F. (2000):"Site Safety Management in Hong Kong” J. Manage. Eng., 16(6), pp. 34-42.

[03] Toole, T. (2002):"Construction Site Safety Roles" J. Constr. Eng. Manage., 128 (3), pp. 203 - 210.

[04] Smallwood, J. and Emuze, F. (2014):"Financial Provision for Construction Health and Safety" Construction Research Congress, pp. 1881-1890.

[05] Koehn, E. and Musser, K. (1983):"OSHA Regulations Effects on Construction” J. Constr. Eng. Manage., 109(2), pp. 233-2

[06] Hassanein, A. and Hanna, R. (2008):"Safety Performance in the Egyptian Construction Industry" J. Constr. Eng. Manage., 134(6), pp. 451-455.

[07] Petersen, D., (1978):'Techniques of Safety Management”, McGraw-Hill, Book Company.

[08] Hammer, Willie, and Price, Dennis (2001):"Occupational Safety Management and Engineering", Prentice Hall, upper saddle, New Jersey, USA.

[09] Kartam, N. A., Flood, I., and Koushki, P. (2000):"Construction Safety in Kuwait: Issues, Procedures, Problems, and Recommendations", Safety Science, Vol. 36, No. 3, pp. 163-184.

[10] Ahcom, Junaid (2004):"A Model for Benchmarking Contractors Project Management Elements in Saudi Arabia", Master thesis, King Fahd University of Petroleum \& Minerals, Dhahran, Saudi Arabia.

[11] Kartam, N. A., and Bouz, Rami G. (1998):"Fatalities and Injuries in the Kuwaiti Construction Industry", Accident Analysis \& Prevention, pp. 805-814.

[12] Martel, Henri P., and Moselhi, Osama (1988):"Construction Safety Management: a Canadian Study", AACE Transaction.

[15] Smith, G. R., and Roth, R. D. (1991):"Safety Programs and the Construction Manager", Journal of Construction Engineering and Management, pp. 360-371.

[16] Wells, J. and Hawkins, J. (2009): Promoting Construction Health and Safety through Procurement: A briefing note for developing countries, London, Engineers Against Poverty, Institution of Civil Engineers (ice).

[17] Behm, M., Veltri, A., and Kleinorge, I. K. (2004): "The cost of safety" Professional Safety, 49(4), pp. 22-29.

[18] Saudi Aramco Construction Safety Manual (CSM), (1993): Forth Revision, pp. 150-165. 